\title{
Alpha-tocopherol and gamma-tocopherol concentration in vegetable oils
}

\author{
Evellyn Câmara GRILO ${ }^{1 *}$, Priscila Nunes COSTA ${ }^{1}$, Cristiane Santos Sânzio GURGEL ${ }^{1}$,
} Andressa Fernanda de Lima BESERRA ${ }^{1}$, Fernanda Niéce de Souza ALMEIDA ${ }^{1}$, Roberto DIMENSTEIN ${ }^{1}$

\begin{abstract}
Vegetable oils are the richest dietary sources of vitamin E. Vitamin E determination levels in foods are of great importance to adjust the ingestion of nutrients by the population. The purpose of this paper is to determine the concentration of alphatocopherol and gamma-tocopherol in vegetable oils and compare the alpha-tocopherol value to the nutritional requirement of vitamin E. The analysis was performed using High Performance Liquid Chromatography. The values expressed as $\mathrm{mg} / \mathrm{kg}$ for alpha and gamma-tocopherol were, respectively, $120.3 \pm 4.2$ and $122.0 \pm 7.9$ in canola oil; $432.3 \pm 86.6$ and $92.3 \pm 9.5$ in sunflower oil; $173.0 \pm 82.3$ and $259.7 \pm 43.8$ in corn oil; $71.3 \pm 6.4$ and $273.3 \pm 11.1$ in soybean oil. A significant difference was encountered between the alpha-tocopherol concentrations in vegetable oils. Similar results were found for gamma-tocopherol, except for corn and soybean oils. It was concluded that the soybean oil was not considered a source of vitamin E. The canola and corn oils were considered sources, and the sunflower oil was considered an excellent source.
\end{abstract}

Keywords: vitamin E; vegetable oils; nutritional recommendations.

\section{Introduction}

Vitamin $\mathrm{E}$ is the most potent lipid-soluble antioxidant in human plasma. Dietary components with antioxidant activity of vitamin E include $\alpha-, \beta-, \gamma$-and $\delta$-tocopherols and $\alpha-, \beta$-, $\gamma$-and $\delta$-tocotrienols. These compounds containing a chromanol ring attached to a saturated phytyl (tocopherols) unsaturated (tocotrienols) and vary as to the number of methyl groups on the chromanol ring (Traber, 2012). Among the tocopherol homologs, the alpha-tocopherol has the highest biological potency (Ortíz et al., 2006).

Digestion of tocopherols and tocotrienols is similar to lipids, so that the emulsification and incorporation into mixed micelles takes place. Then, these compounds are absorbed by the enterocytes and transported primarily in the proximal intestine. In these cells, the tocopherols are incorporated into chylomicrons and transported by the lymphatic system (Nagy et al., 2013).

Os chylomicrons reach the blood circulation, where its triglycerides are hydrolyzed by the lipoprotein lipase (Asakura, 2006). Tocopherols reach the liver via the remnant chylomicrons and alpha-tocopherol is preferably incorporated into VLDLs by having greater affinity for the transport protein alpha -tocopherol ( $\alpha$-tocopherol transport protein or $\alpha$-TTP). Therefore, alpha-tocopherol is the isomer that is in higher concentrations in plasma and tissues (Fu et al., 2014).

Several reactive oxygen / nitrogen species induce oxidative stress. The removal of these compounds is the main function of antioxidants, vitamin $\mathrm{E}$ being the most important and abundant fat-soluble antioxidant in vivo. The peroxyl radicals are removed by vitamin $\mathrm{E}$ in order to disrupt and inhibit lipid peroxidation reactions (Niki, 2014). The alpha-tocopherol presents anti- inflammatory activity and modulates the expression of proteins involved in cholesterol metabolism (Wallert et al., 2014).

At the post-translational level, the alpha-tocopherol modulates proteins, such as kinase, lipoxygenase and phospholipase A2. At the transcriptional level, this compound is capable to modulate the transcription of the genes involved in the cell signaling and regulation of the cell cycle. The alphatocopherol also has the function of cell proliferation inhibition, platelet aggregation and monocytes adhesion (Azzi et al., 2004; Zingg \& Azzi, 2004).

Gamma-tocopherol is regarded as the most potent freeradical remover $\mathrm{NO}(\mathrm{X})$ among the isomers of vitamin $\mathrm{E}$. In addition, studies show that gamma-tocopherol has strong anti-inflammatory activity and is related to inhibition of carcinogenesis (Ju et al., 2010).

The vitamin E deficiency has been reported primarily in preterm infants, patients with severe malnutrition, genetic disorders of lipid metabolism and chronic gastrointestinal diseases. The main symptoms of this vitamin deficiency is hemolytic anemia and neurological symptoms (ataxia, peripheral neuropathy, myopathy, pigmentary retinopathy) (Péter et al., 2013).

Gamma-tocopherol is the most abundant tocopherol in the American diet; however, only alpha-tocopherol is related to the daily requirement of vitamin $\mathrm{E}$, which makes this vitamin one of the most difficult nutrients obtained from the diet. Only $8 \%$ of men and $2 \%$ of women in the United States reach the estimated average requirement (Traber, 2006). A study performed with 2344 Brazilian adults verified a low daily ingestion of alpha-tocopherol, which average was lower

${ }^{1}$ Department of Biochemistry, BioScience Center, Federal University of Rio Grande do Norte (UFRN), Natal, RN, Brazil, e-mail: evellyn-cg@hotmail.com 
than $50 \%$ of the recommended ingestion for the population mentioned (Pinheiro et al., 2011).

The richest dietary sources of vitamin $\mathrm{E}$ are vegetable oils. Other important sources of this vitamin are whole grains and nuts (Traber, 2012).

Triacylglycerols are the predominant components of vegetable fats and oils. Minor compounds include: mono-and diglycerides, free fatty acids, sterols, tocopherols, among others. Tocopherols play an important role for inhibiting the lipid oxidation in vegetable oils. The result of the autoxidation of fats and oils is the development of objectionable flavors and odors characteristic of the condition known as "oxidative rancidity" (Asif, 2011).

The determination of the minor compounds of vegetable oils, among them the tocopherol group, is essential for analytical evaluation of the quality, origin, extraction method, refining and possible adulteration that might occur in this product (Cert et al., 2000).

The control of vitamin E levels in foods is also of great importance to ensure that the daily ingestion is adequate, as this is an essential factor for good health (Sánchez-Pérez et al., 2000). In order to adjust the ingestion of nutrients by the population it is important to know the main food-sources, as well as the most consumed foods (Batista et al., 2007). There is little information concerning the concentration of vitamin $\mathrm{E}$ in foods sold in Brazil and the main tables of food composition do not have data concerning vitamin E content, or only show data of total tocopherol, without specifying the concentration of each isomer in the food.

The purposes of this paper was to determine the concentration of alpha- and gamma-tocopherol of vegetable oils acquired in large supermarkets of the city of Natal/RN and the relation of the values found for alpha-tocopherol to the nutritional requirement of vitamin $\mathrm{E}$ for adults.

\section{Materials and methods}

\subsection{Samples}

Four types of vegetable oils were analyzed: canola, sunflower, corn and soybean. Out of each type of oil, 3 main brands were analyzed. Out of each brand, 2 different batches were acquired and 2 bottles were acquired of each batch. This methodology was elaborated based on the sampling plan of industrialized products of the Brazilian Table of Food Composition (Universidade Estadual de Campinas, 2011). Moreover vegetable oils with labels that did not inform that it had the addition of tocopherols to the product were also selected.

Vegetable oils which manufacture had occurred until one month before the date of analysis. The selection of oils was performed at large supermarkets of Natal/RN and these products were transported to the Biochemistry Laboratory of Foods and Nutrition, located in the Department of Biochemistry of the Federal University of Rio Grande do Norte (RN), Brazil.

\subsection{Dilution of the samples}

For sample preparation, the dilution of $40 \mu \mathrm{L}$ of certain types of vegetable oil in $960 \mu \mathrm{L}$ of dichloromethane was performed (UV/HPLC - Vetec, Rio de Janeiro, Brazil) and shaken for 1 minute. The dichloromethane was chosen for the dilution because it allows a good solubility of oils and is also miscible with the solvent used in the mobile phase (methanol).

\subsection{Determination of alpha-and gamma-tocopherol using High Performance Liquid Chromatography}

After the dilution of the vegetable oil, direct injection of the sample was performed for the determination of the alpha and gamma-tocopherol through High Performance Liquid Chromatography (HPLC). For this purpose, $20 \mu \mathrm{L}$ was applied in the Shimadzu chromatograph, using AD LC-10 Shimadzu pump, connected to a SPD-10A Shimadzu UV-VIS Detector and Chromatopac C-R6A Shimadzu Integrator to a LC Perkin Elmer CLC-ODS column (M) $4.6 \mathrm{~mm} \times 25 \mathrm{~cm}$. The mobile phase was methanol at $100 \%$, in an isocratic system with 1.0 $\mathrm{mL} / \mathrm{min}$ flow and wavelength of $292 \mathrm{~nm}$.

The chromatographic method using detection by ultraviolet or fluorescence was standardized according to IUPAC and AOCS standards (Cert et al., 2000). The HPLC use, in a reverse phase, is not capable to separate beta- and gamma-tocopherol. However, for edible vegetable oils, this was presented as a minimum error of quantification, since, in accordance with the literature, the oils do not contain beta-tocopherol or contain relatively small amounts $(0-28.0 \mathrm{mg} / \mathrm{kg}$ depending on the analyzed oil) in comparison to the gamma-tocopherol (Gliszczynska-Swigło \& Sikorska, 2004).

The identification and quantification of the alphatocopherol and gamma-tocopherol in the samples had been established by comparison with the time of retention and the area of the respective standards (Figure 1). The concentration of the standards was confirmed by the specific extinguishing coefficient ( $\varepsilon 1 \%, 1 \mathrm{~cm}=75.8$ to $292 \mathrm{~nm}$ for alpha-tocopherol and $\varepsilon 1 \%, 1 \mathrm{~cm}=91.4$ to $298 \mathrm{~nm}$ for gamma-tocopherol), both in absolute ethanol (Merck, São Paulo, Brazil) (Nierenberg \& Nann, 1992; Podda et al., 1996). The analytical procedure of sample preparation and of the standards was performed under a temperature of about $25^{\circ} \mathrm{C}$ and in pipes packed with paper aluminum.

The linearity of the method was verified through the calibration curves for the alpha-tocopherol and the gammatocopherol. These were constructed by a linear regression (concentrations of standards $\times$ standards area) and a value of $r^{2}=0.9992$ and $r^{2}=0.9999$ were obtained for the alphatocopherol and the gamma-tocopherol, respectively. The limits of detection and quantification of alpha-tocopherol had been based on the linearity of the standard curve, obtaining the values of $13 \mathrm{ng} / 20 \mu \mathrm{L}$ and $26 \mathrm{ng} / 20 \mu \mathrm{L}$, respectively. The limits of detection and quantification of gamma-tocopherol had been based on the linearity of the standard curve, obtaining the values of $5,75 \mathrm{ng} / 20 \mu \mathrm{L}$ and $11,50 \mathrm{ng} / 20 \mu \mathrm{L}$, respectively. The precision of the method was verified through repetition of the test, and the variation coefficient was lower than $4 \%$. 


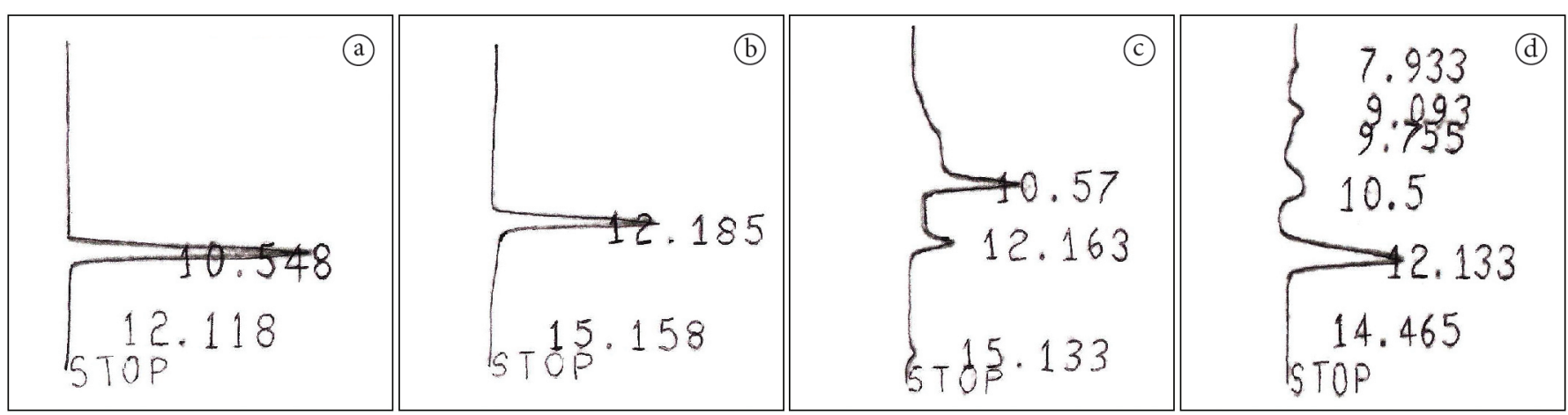

Figure 1. Chromatographic profile of gamma- and alpha-tocopherol. Caption: (a) Standard reference gamma-tocopherol and retention time of 10.5 minutes. (b) Reference standard for alpha-tocopherol and retention time of 12.2 minutes. Elution peaks of gamma-and alpha-tocopherol in sample: (c) canola oil and (d) sunflower oil.

\subsection{Statistical analysis}

The concentration of alpha and gamma-tocopherol in the vegetable oils analyzed were expressed as average and standard deviations, and the unit used was $\mathrm{mg} / \mathrm{kg}$ of vegetable oil. For statistical analysis the software Statistica 7 was used (StatSoft, Inc., Tulsa, OK, USA). In order to compare the average concentrations of alpha- and gamma-tocopherol between brands and types of analyzed oils the test of Variance Analysis was performed (ANOVA), with Tukey's post-hoc test. The differences were considered significant with $\mathrm{p}<0.05$.

\subsection{Relation between the recommended portion of oils and the requirement of vitamin $E$}

In accordance with the Alimentary Guide for the Brazilian Population, the recommended consumption of oils, fats or seeds is of 1 portion per day. In relation to the domestic measure of vegetable oils, this portion corresponds to 1 soup spoon of oil or $8 \mathrm{~g}$ (Brasil, 2008). Following this recommendation, the amount of alpha-tocopherol contained in 1 portion of each type of vegetable oil was calculated and its relation with the daily nutritional requirement of vitamin $\mathrm{E}$ was verified, the equivalent to $15 \mathrm{mg}$ (Institute of Medicine, 2000). After that, the vegetable oils were classified as a good to excellent food source. A food is considered a food source when it contains more than $5 \%$ of the value of the DRI (RDA or AI) in a normal portion; a good source is the one that contains between $10 \%$ and $20 \%$, and an excellent source is the food that contains above $20 \%$ of the DRI (RDA or AI) in an usual portion (Philippi, 2008).

\section{Results}

\subsection{Concentration of tocopherols in vegetable oils}

Regarding the quantitative analysis, the following average concentrations of alpha-tocopherol referring to each type of oil were found: (120.3 \pm 4.2$) \mathrm{mg} / \mathrm{kg}$ of canola oil; $(432.3 \pm 86.6) \mathrm{mg} / \mathrm{kg}$ of sunflower oil; $(173.0 \pm 82.3) \mathrm{mg} / \mathrm{kg}$ of corn oil and $(71.3 \pm 6.4)$ $\mathrm{mg} / \mathrm{kg}$ of soybean oil.

In relation to gamma-tocopherol concentrations the following results were found: $122.0 \pm 7.9 \mathrm{mg} / \mathrm{kg}$ of canola oil;
$92.3 \pm 9.5 \mathrm{mg} / \mathrm{kg}$ of sunflower oil; $259.7 \pm 43.8 \mathrm{mg} / \mathrm{kg}$ of corn oil and $273.3 \pm 11.1 \mathrm{mg} \mathrm{kg}$ of soybean oil.

After statistical analysis, a significant difference between the alpha-tocopherol concentrations was verified in the oils evaluated. After comparison between the gamma-tocopherol concentrations in the analyzed products, it was noted that there is a statistically significant difference between the types of oils, except among corn and soybean oils $(\mathrm{p}=0.286)$. Considering that, it is noted that the lipid portion of grains or seeds of which the vegetable oils are extracted has well distinct concentrations of tocopherols.

\subsection{Concentration of tocopherol by vegetable oils brands}

The concentrations of alpha- and gamma-tocopherol in vegetable oils related to the analyzed brand are shown in Tables 1 and 2 .

It was verified that there isn't a significant difference between the alpha-tocopherol concentrations in the three analyzed brands of canola oils as well as of the soybean oils (Table 1). A similar result was verified for the gamma-tocopherol concentration (Table 2).

However, in relation to the concentration of alphatocopherol in the sunflower oil, it was observed that the brand $\mathrm{C}$ has a concentration significantly lower than the brands A $(\mathrm{p}=0.000)$ and $\mathrm{B}(\mathrm{p}=0.000)$ (Table 1$)$. In relation to gammatocopherol in this oil, it was verified that the brand $\mathrm{B}$ has a higher concentration than the brands $\mathrm{A}(\mathrm{p}=0.003)$ and $\mathrm{C}(\mathrm{p}=0.000)$ (Table 2). Regarding the corn oil, the gamma-tocopherol and alpha-tocopherol concentrations are significantly higher in brand $\mathrm{C}$ in comparison to the brands $\mathrm{A}(\mathrm{p}=0.000)$ and $\mathrm{B}$ $(\mathrm{p}=0.000)$ (Tables 1 and 2$)$.

\subsection{Tocopherol distribution in vegetable oils}

It was observed that, among the analyzed products, the richest in alpha-tocopherol are the sunflower and corn oils. Moreover, the gamma-tocopherol has a higher concentration in soybean and corn oils. It was also observed that the 
Table 1. Concentration of alpha-tocopherol in vegetable oils, by product brand.

\begin{tabular}{ccccc}
\hline \multirow{2}{*}{ Brand } & \multicolumn{4}{c}{ Concentration by type of oil $(\mathrm{mg} / \mathrm{kg})$} \\
\cline { 2 - 5 } & Canola & Sunflower & Corn & Soybean \\
\hline A & $125.0 \pm 8.0$ & $497.0 \pm 35.0$ & $122.0 \pm 14.0$ & $75.0 \pm 17.0$ \\
B & $119.0 \pm 56.0$ & $466.0 \pm 55.0$ & $129.0 \pm 12.0$ & $64.0 \pm 18.0$ \\
C & $117.0 \pm 32.0$ & $334.0 \pm 31.0^{*}$ & $268.0 \pm 50.0^{*}$ & $75.0 \pm 19.0$ \\
Average \pm SD & $120.3 \pm 4.2$ & $432.3 \pm 86.6$ & $173.0 \pm 82.3$ & $71.3 \pm 6.4$ \\
\hline
\end{tabular}

Values referring to the average \pm standard deviation of the alpha-tocopherol concentration between 2 different batches of each vegetable oil brand analyzed. Significantly different average, by column $(\mathrm{p}<0.05)^{*}$. SD: standard deviation.

Table 2. Concentration of gamma-tocopherol in vegetable oils, by product brand.

\begin{tabular}{ccccc}
\hline \multirow{2}{*}{ Brand } & \multicolumn{4}{c}{ Concentration by type of oil $(\mathrm{mg} / \mathrm{kg})$} \\
\cline { 2 - 5 } & Canola & Sunflower & Corn & Soybean \\
\hline A & $128.0 \pm 8.0$ & $89.0 \pm 8.0$ & $230.0 \pm 33.0$ & $263.0 \pm 49.0$ \\
B & $125.0 \pm 51.0$ & $103.0 \pm 16.0^{*}$ & $239.0 \pm 17.0$ & $285.0 \pm 59.0$ \\
C & $113.0 \pm 31.0$ & $85.0 \pm 15.0$ & $310.0 \pm 42.0^{*}$ & $272.0 \pm 42.0$ \\
Average \pm SD & $122.0 \pm 7.9$ & $92.3 \pm 9.5$ & $259.7 \pm 43.8$ & $273.3 \pm 11.1$ \\
\hline
\end{tabular}

Values referring to the average \pm standard deviation of the gamma-tocopherol concentration between 2 different batches of each brand of vegetable oil analyzed. Significantly different average, by column $(\mathrm{p}<0.05)^{*}$. SD: standard deviation.

concentration of alpha- and gamma-tocopherol in the canola oil is similar (Figure 2).

\subsection{Vegetable oils as food source of vitamin $E$}

Considering the amount of alpha-tocopherol in the portion of oils recommended (Figure 3), it was found that a portion of canola, sunflower, corn and soybean oil are equivalent, respectively, to $6.4 \% ; 23.1 \% ; 9.2 \%$ and $3.8 \%$ of the nutritional requirement of vitamin $\mathrm{E}$. Thus, the soybean oil was not considered as a food-source, the canola and corn oils were classified as a food source, and the sunflower oil as an excellent source of vitamin $\mathrm{E}$.

\section{Discussion}

Vitamin $\mathrm{E}$ is the main fat-soluble vitamin in vegetable oils, which contain concentrations of total tocopherols in the range of $200-1000 \mathrm{mg} / \mathrm{kg}$. These compounds are generally derived from the extraction of oil seeds (Chen et al., 2011).

The concentration of alpha-tocopherol found in the canola oil was lower than the value displayed on the food table composition of the United States Department of Agriculture (2008) $(175.0 \mathrm{mg} / \mathrm{kg})$. It was also lower than the values found in Canada $(274.0 \mathrm{mg} / \mathrm{kg})$, Chile $(247.0 \mathrm{mg} / \mathrm{kg})$ and Brazil (184.0 mg/kg; $269.0 \mathrm{mg} / \mathrm{kg}$ ) (Ahmed et al., 2005; Romero et al., 2007; Guinazi et al., 2009; Branco, 2009). On the other hand, the concentration of alpha-tocopherol obtained in this study was higher than the value found in a study conducted in Costa Rica (69.0 mg/kg) (Monge-Rojas \& Campos, 2011). In relation to the gamma-tocopherol concentration, it was verified that the values found are lower than the value found in Canada (237.0 mg/kg) (Ahmed et al., 2005), in Brazil (442.0 mg/kg;

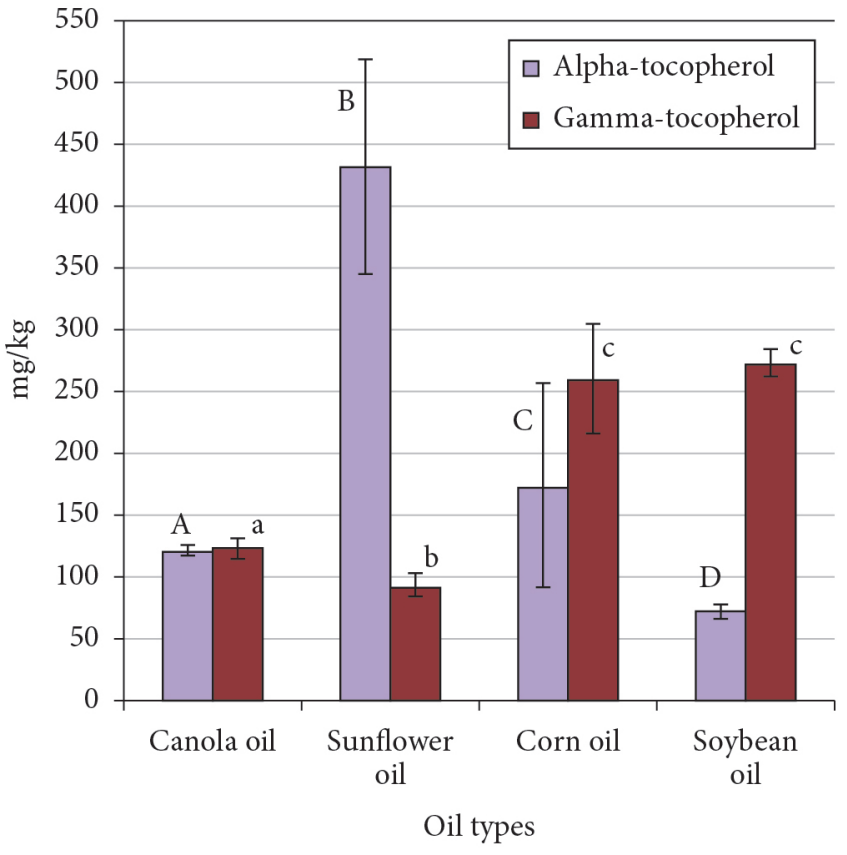

Figure 2. Distribution of alpha- and gamma-tocopherol concentration in vegetable oils. Caption: Concentration of alpha-tocopherol in vegetable oils (letter A - D). Gamma-tocopherol concentration in vegetable oils $(\mathrm{a}-\mathrm{c})$. Averages identified with different capital letters when the concentration of alpha-tocopherol between the oils presented significant difference $(\mathrm{p}<0.05)$, Variance Analysis (ANOVA). Averages identified with different small letters when the concentration of gammatocopherol between oils presented significant difference $(\mathrm{p}<0.05)$, Variance Analysis (ANOVA).

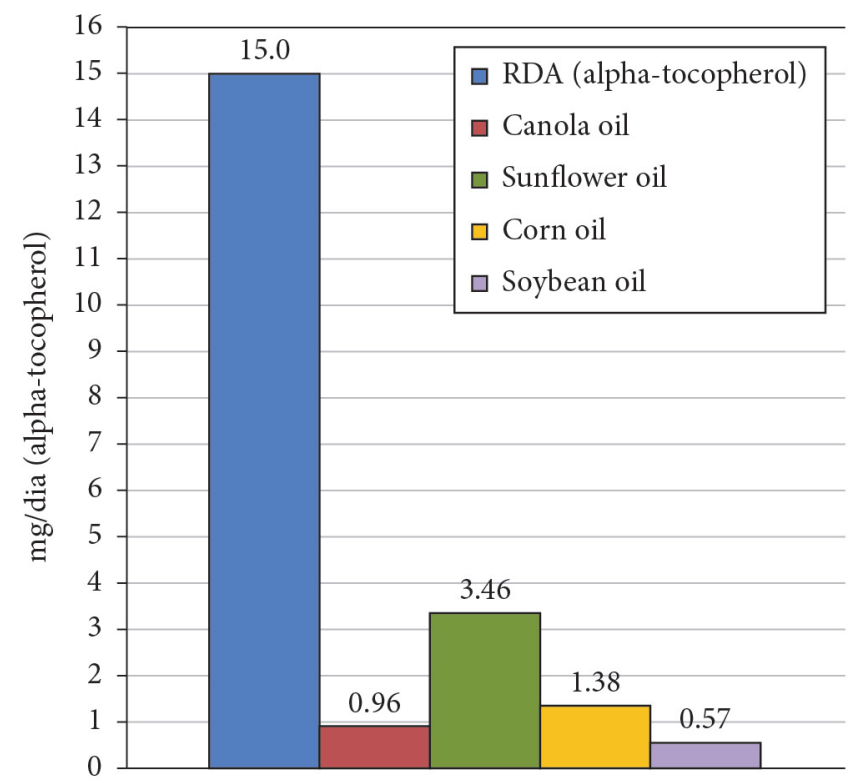

Figure 3. Alpha-tocopherol in vegetable oils analyzed considering the portion recommended for this group of foods. Caption: Nutritional requirement of vitamin E: $15 \mathrm{mg} /$ day. Alpha-tocopherol (mg) contained in 8 grams of vegetable oil (recommended portion/day). 
$501.0 \mathrm{mg} / \mathrm{kg}$ ) (Guinazi et al., 2009; Branco, 2009), in Chile $(348.0 \mathrm{mg} / \mathrm{kg}$ ) (Romero et al., 2007) and in the American food table $(273.0 \mathrm{mg} / \mathrm{kg}$ ) (United States Department of Agriculture, 2008) and is in accordance with the results obtained in Costa Rica (100.0 mg/kg) (Monge-Rojas \& Campos, 2011).

In relation to the sunflower oil, it was observed that the alpha-tocopherol concentration was similar to the concentration found on the food table composition of the United States Department of Agriculture (2008) and in Lechner's paper et al. (1999) $(411.0 \mathrm{mg} / \mathrm{kg}$ and $425.0 \mathrm{mg} / \mathrm{kg}$, respectively). Moreover, it is higher than the result found by Ortíz et al. (2006) (359.0 $\mathrm{mg} / \mathrm{kg}$ ) and by Monge-Rojas \& Campos (2011) (150.0 mg/ $\mathrm{kg}$ ). However, the concentration found was lower than the concentration found by Barrera-Arellano et al. (2002), Franke et al. (2007), Branco (2009), Gliszczyńska-Świgło et al. (2007), Kamal-Eldin (2006) and Schwartz et al. (2008), that were $575.0 \mathrm{mg} / \mathrm{kg} ; 541.8 \mathrm{mg} / \mathrm{kg} ; 666.0 \mathrm{mg} / \mathrm{kg} ; 575.0 \mathrm{mg} / \mathrm{kg} ; 671.0$ $\mathrm{mg} / \mathrm{kg}$ and $590.0 \mathrm{mg} / \mathrm{kg}$, respectively. In relation to the gammatocopherol concentration, it was noted that the value found in our paper was higher than the value found in the literature (Ortíz et al., 2006; Branco, 2009; Monge-Rojas \& Campos, 2011; Lechner et al., 1999; Barrera-Arellano et al., 2002; Franke et al., 2007; Gliszczyńska-Świgło et al., 2007; Kamal-Eldin, 2006; Schwartz et al., 2008).

It was verified that the concentration of alpha-tocopherol in the corn oil analyzed had similar value to the value found in the food table composition of the United States Department of Agriculture (2008) $(143.0 \mathrm{mg} / \mathrm{kg})$ and to the value found in studies performed in Brazil $(169.0 \mathrm{mg} / \mathrm{kg}$ ) (Lima \& Gonçalves, 1997) and in Austria (180.0 mg/kg) (Schwartz et al., 2008). However, it was lower than the value found in Egypt $(417.0 \mathrm{mg} /$ $\mathrm{kg}$ ) (Ramadan \& Wahdan, 2012), in the United States $(222.1 \mathrm{mg} /$ $\mathrm{kg}$ ) (Franke et al., 2007), Brasil (240.0 mg/kg) (Branco, 2009), Poland (207.0 mg/kg) (Gliszczyńska-Świgło et al., 2007), Sweden $(222.0 \mathrm{mg} / \mathrm{kg})$ (Kamal-Eldin, 2006) and Spain $(204.0 \mathrm{mg} / \mathrm{kg})$ (Sánchez-Pérez et al., 2000). However, the concentration of alpha-tocopherol was higher than the value obtained in Costa Rica $(69 \mathrm{mg} / \mathrm{kg}$ ) (Monge-Rojas \& Campos, 2011). Regarding the concentration of gamma-tocopherol found in the corn oil, it was verified that this is lower than the concentration found in the literature and similar to that obtained by Monge-Rojas and Campos (2011) (220 mg/kg) (Sánchez-Pérez et al., 2000; Branco, 2009; Franke et al., 2007; Gliszczyńska-Świgło et al., 2007; Kamal-Eldin, 2006; Schwartz et al., 2008; Lima \& Gonçalves, 1997; Ramadan \& Wahdan, 2012).

The concentration of alpha-tocopherol in the soybean oil analyzed is similar to the concentration in the work performed in Canada ( $92.8 \mathrm{mg} / \mathrm{kg}$ ) (Ahmed et al., 2005) and found in the food table composition of the United States Department of Agriculture (2008) $(81.8 \mathrm{mg} / \mathrm{kg})$. However, it is lower than the concentration found in Spain $(149.0 \mathrm{mg} /$ $\mathrm{kg}$ ) (Barrera-Arellano et al., 2002), Poland (152.0 mg/kg) (Gliszczyńska-Świgło et al., 2007), Brazil (Guinazi et al., 2009; Lima \& Gonçalves, 1997; Branco, 2009; Carvalho et al., 2008) $(121.0 \mathrm{mg} / \mathrm{kg}, 134.0 \mathrm{mg} / \mathrm{kg}, 181.0 \mathrm{mg} / \mathrm{kg}, 180.1 \mathrm{mg} / \mathrm{kg})$ and Sweden (116.0 mg/kg) (Kamal-Eldin, 2006). Moreover, this concentration obtained appeared higher than that in a study conducted in Costa Rica $(25.0 \mathrm{mg} / \mathrm{kg}$ ) (Monge-Rojas \& Campos, 2011). The concentration of gamma-tocopherol in the soybean oil was lower than the values found in the literature and higher to that result found in Costa Rica $(210.0 \mathrm{mg} / \mathrm{kg}$ ) (Ahmed et al., 2005; Guinazi et al., 2009; Branco, 2009; Monge-Rojas \& Campos, 2011; Barrera-Arellano et al., 2002; GliszczyńskaŚwigło et al., 2007; Kamal-Eldin, 2006; Lima \& Gonçalves, 1997; Carvalho et al., 2008).

The tocopherols are one of the main groups regarding the portion of the minor compounds in vegetable oils. Oils originated from the same species can have variable content and composition of these minor compounds, due to climatic and agronomic conditions; fruit quality or seed origin; oil extraction system and refining procedure (Cert et al., 2000).

Traditionally, the purpose of the vegetable oils refining is to eliminate all the impurities in crude oils in order to get a vegetable oil of good quality (Medina-Juárez et al., 2000). The volatility of tocopherols is less than free fatty acids and greater than the triacylglycerols. Thus, during the refining process, tocopherols are partially lost during deodorization (Chen et al., 2011). A study of sunflower oil showed that the concentration of tocopherols and isomers, individually analyzed are reduced during refining of vegetable oils (Naz et al., 2011).

Considering the high potential of anti-oxidant of tocopherols in vegetable oils and the nutritional contribution of vitamin E, it is evident that the establishment of the ideal operational conditions is important during the refining process in order to reduce the loss of these tocopherols (MedinaJuárez et al., 2000).

The variability in the vegetable oils composition by intrinsic or external factors can be related to the concentrations of alpha and gamma-tocopherol found in our work, which are conflicting with the literature. The food industries must verify the origin of the grain or seed and select raw material of higher quality for production of vegetable oils. Moreover, the conditions of culture, storage and processing of the seeds or grains must be proper and constantly evaluated and monitored for the preservation of the organoleptic and nutritional quality of the final product.

Considering the differences between the several brands, the hypothesis is that the factors mentioned by Cert et al. (2000) and by Medina-Juárez et al. (2000) can have influenced the alpha- and gamma-tocopherol concentration in the sunflower and corn oils analyzed.

The richest in alpha-tocopherol are the sunflower and corn oils. This information regarding the sunflower oil is in accordance with the statement that this compound is found in higher concentrations in wheat germ oils, olive oil and sunflower oil (Traber, 2006; Gliszczyńska-Świgło et al., 2007; Smolarek \& Suh, 2011; Velasco et al., 2010).

The gamma-tocopherol has a higher concentration in soybean and corn oils and similar information was related by Traber (2006) and by Gliszczyńska-Świgło et al. (2007). The tocopherol ratio varies according to the oil type, as well as by other factors, for example, climate and origin of the culture (Ortíz et al., 2006). 
Some studies reported the inadequate ingestion of alphatocopherol (Traber, 2006; Pinheiro et al., 2011). Considering this, it is important to verify the relation between the alphatocopherol concentration in the oils analyzed and the nutritional requirement of vitamin E. According to the Dietary Reference Intakes (DRI), the daily recommendation of vitamin $\mathrm{E}$ for healthy individuals from 14 years is of $15 \mathrm{mg}$ of alpha-tocopherol (Institute of Medicine, 2000). This recommendation is based on studies of vitamin deficiency induced in humans and in trials of hemolysis in vitro caused by hydrogen peroxide (Ramalho et al., 2006).

Despite the gamma-tocopherol predominance in the detriment of alpha-tocopherol in soybean oil, this product is the main contributor for the ingestion of vitamin $\mathrm{E}$ for the population (Guinazi, 2004). Considering the findings of this paper, the consumption of oils with higher concentrations of alpha-tocopherol (sunflower and corn) needs to be stimulated in order to improve the ingestion of this vitamin.

\section{Conclusions}

It is concluded that the sunflower and corn oils have the highest concentrations of alpha-tocopherol, wheras the vegetable oils with higher concentrations of gamma-tocopherol were the soybean and corn oils. Moreover, the soybean oil was not considered as a food source of vitamin E, the canola and corn oils had been classified as a food source and the sunflower oil was considered as an excellent source of this vitamin.

\section{Acknowledgements}

To CNPq (Conselho Nacional de Desenvolvimento Científico e Tecnológico) for the Scientific Initiation scholarship (PIBIC modality).

\section{References}

Ahmed, M. K., Daun, J. K., \& Przybylski, R. (2005). FT-IR based methodology for quantitation of total tocopherols, tocotrienols and plastochromanol-8 in vegetable oils. Journal of Food Composition and Analysis, 18(5), 359-364. http://dx.doi.org/10.1016/j. jfca.2003.12.008

Asakura, L. (2006). Vitamina E. In M. A. Cardoso (Ed.), Nutrição Humana: Nutrição e Metabolismo (cap. 7, pp. 112-124). Rio de Janeiro: Editora Guanabara.

Asif, M. (2011). General Chemistry, Composition, Identification and Qualitative Tests of Fats or Oils. JPRO, 1(2), 52-64.

Azzi, A., Gysin, R., Kempná, P., Munteanu, A., Negis, Y., Villacorta, L., Visarius, T., \& Zingg, J. (2004). Vitamin E mediates cell signaling and regulation of gene expression. Annals of the New York Academy of Sciences, 1031, 86-95. PMid:15753136. http://dx.doi.org/10.1196/ annals.1331.009

Barrera-Arellano, D., Ruiz-Méndez, V., Velasco, J., Márquez-Ruiz, G., \& Dobarganes, C. (2002). Loss of tocopherols and formation of degradation compounds at frying temperatures in oils differing in degree of unsaturation and natural antioxidant content. Journal of the Science of Food and Agriculture, 82(14), 1696-1702. http://dx.doi. org/10.1002/jsfa.1245
Batista, E. S., Costa, A. G. V., \& Pinheiro-Sant’Ana, H. M. (2007). Adição da vitamina $\mathrm{E}$ aos alimentos: implicações para os alimentos e para a saúde humana. Revista de Nutrição, 20(5), 525-535. http://dx.doi. org/10.1590/S1415-52732007000500008

Branco, V. N. C. (2009). Capacidade antioxidante total de oleos vegetais refinados: contribuicao ao estudo de seus determinantes (Dissertação de mestrado). Universidade Federal do Rio de Janeiro, Rio de Janeiro.

Brasil, Ministério da Saúde. (2008). Guia Alimentar para População Brasileira promovendo a alimentação saudável (Normas e manuais técnicos). Brasília.

Carvalho, S. M., Ogliari, P. J., Barrera-Arellano, D., \& Block, J. M. (2008). Efeito da adição de tocoferóis naturais sobre a qualidade de óleo de soja refinado e embalado em PET durante a estocagem. Brazilian Journal of Food Technology, 11(2), 134-143.

Cert, A., Moreda, W., \& Pérez-Camino, M. C. (2000). Chromatographic analysis of minor constituents in vegetable oils. Journal of Chromatography A, 881(1-2), 131-148. http://dx.doi.org/10.1016/ S0021-9673(00)00389-7

Chen, B., McClements, D. J., \& Decker, E. A. (2011). Minor Components in Food Oils: A Critical Review of their Roles on Lipid Oxidation Chemistry in Bulk Oils and Emulsions. Critical Reviews in Food Science and Nutrition, 51(10), 901-916. PMid:21955091. http:// dx.doi.org/10.1080/10408398.2011.606379

Franke, A. A., Murphy, S. P., Lacey, R., \& Custer, L. J. (2007). Tocopherol and Tocotrienol Levels of Foods Consumed in Hawaii. Journal of Agricultural and Food Chemistry, 55(3), 769-778. Pmid:17263473. http://dx.doi.org/10.1021/jf0623844

Fu, J., Che, H., Tan, D. M., \& Teng, K. (2014). Bioavailability of tocotrienols: evidence in human studies. Nutrition and Metabolism, 11(5), 1-10.

Gliszczynska-Swigło, A., \& Sikorska, E. (2004). Simple reversed-phase liquid chromatography method for determination of tocopherols in edible plant oils. Journal of Chromatography A, 1048(2), 195-198. PMid:15481256. http://dx.doi.org/10.1016/j.chroma.2004.07.051

Gliszczyńska-Świgło, A., Sikorska, E., Khmelinskii, I., \& Sikorski, M. (2007). Tocopherol content in edible plant oils. Polish Journal Of Food And Nutrition Sciences, 57(4), 157-161.

Guinazi, M. (2004). Tocoferóis e tocotrienóis em hortaliças, ovos e óleos vegetais utilizados em restaurantes comerciais (Dissertação de mestrado). Universidade Federal de Viçosa, Viçosa.

Guinazi, M., Milagres, R. C. R. M., Pinheiro-Sant'Ana, H. M., \& Chaves, J. B. P. (2009). Tocoferóis e tocotrienois em óleos vegetais e ovos. Quimica Nova, 32(8), 2098-2103. http://dx.doi.org/10.1590/S010040422009000800021

Institute of Medicine - IOM. (2000). Dietary Reference Intakes for Vitamin C, Vitamin E, Selenium, and Carotenoids. Washington: National Academy Press.

Ju, J., Picinich, S. C., Yang, Z., Zhao, Y., Suh, N., Kong, A.-N., \& Yang, C. S. (2010). Cancer-preventive activities of tocopherols and tocotrienols. Carcinogenesis, 31(4), 533-542. PMid:19748925 PMCid:PMC2860705. http://dx.doi.org/10.1093/carcin/bgp205

Kamal-Eldin, A. (2006). Effect of fatty acids and tocopherols on the oxidative stability of vegetable oils. European Journal of Lipid Science and Technology, 108(12), 1051-1061. http://dx.doi.org/10.1002/ ejlt.200600090

Lechner, M., Reiter, B., \& Lorbeer, E. (1999). Determination of tocopherols and sterols in vegetable oils by solid-phase extraction and subsequent capillary gas chromatographic analysis. Journal of 
Chromatography A, 857(1-2), 231-238. http://dx.doi.org/10.1016/ S0021-9673(99)00751-7

Lima, J. R., \& Gonçalves, L. A. G. (1997). Quantificação de tocoferóis em óleos de milho, soja, castanha-do-pará e castanha de caju por Cromatografia Líquida de Alta Eficiência em fase reversa. Alimentos e Nutrição, 8(1), 65-73.

Medina-Juárez, L. A., Gámez-Meza, N., Ortega-García, J., NoriegaRodriguez, J. Á., \& Angulo-Guerrero, O. (2000). Trans Fatty Acid Composition and Tocopherol Content in Vegetable Oils Produced in Mexico. Journal of the American Oil Chemists' Society, 77(7), 721-724. http://dx.doi.org/10.1007/s11746-000-0116-3

Monge-Rojas, R., \& Campos, H. (2011). Tocopherol and carotenoid content of foods commonly consumed in Costa Rica. Journal of Food Composition and Analysis, 24(2), 202-216. http://dx.doi. org/10.1016/j.jfca.2010.09.015

Nagy, K., Ramos, L., Courtet-Compondu, M.-C., Braga-Lagache, S., Redeuil, K., Lobo, B., Azpiroz, F., Malagelada, J-R., Beaumont, M., Moulin, J., Acquistapache, S., Sagalowicz, L., Kussmann, M., Santos, J., Holst, B., \& Williamson, G. (2013). Double-balloon jejunal perfusion to compare absorption of vitamin $\mathrm{E}$ and vitamin $\mathrm{E}$ acetate in healthy volunteers under maldigestion conditions. European Journal of Clinical Nutrition, 67(2), 202-206. PMid:23212132. http:// dx.doi.org/10.1038/ejcn.2012.183

Naz, S., Sherazi, S. T. H., \& Talpur, F. N. (2011). Changes of Total Tocopherol and Tocopherol Species During Sunflower Oil Processing. Journal of the American Oil Chemists' Society, 88(1), 127-132. http://dx.doi.org/10.1007/s11746-010-1652-4

Nierenberg, D. W., \& Nann, S. L. (1992). A method for determining concentrations of retinol, tocopherol, and five carotenoids in human plasma and tissue samples. American Journal of Clinical Nutrition, 56(2), 417-426. PMid:1636620.

Niki, E. (2014). Role of vitamin E as a lipid-soluble peroxyl radical scavenger: in vitro and in vivo evidence. Free Radical Biology \& Medicine, 66(8), 3-12. PMid:23557727. http://dx.doi.org/10.1016/j. freeradbiomed.2013.03.022

Ortíz, C. M. L., Moya, M. S. P., \& Navarro, V. B. (2006). A rapid chromatographic method for simultaneous determination of $\beta$-sitosterol and tocopherol homologues in vegetable oils. Journal of Food Composition and Analysis, 19(2), 141-149. http://dx.doi. org/10.1016/j.jfca.2005.06.001

Péter, S., Moser, U., Pilz, S., Eggersdorfer, M., \& Weber, P. (2013). The Challenge of Setting Appropriate Intake Recommendations for Vitamin E: Considerations on Status and Functionality to Define Nutrient Requirements. International Journal for Vitamin and Nutrition Research, 83(2), 129-136. Pmid:24491886. http://dx.doi. org/10.1024/0300-9831/a000153

Philippi, S. T. (2008). Alimentação Saudável e a pirâmide dos alimentos. In S. T. Philippi (Ed.), Pirâmide dos Alimentos: Fundamentos básicos da Nutrição (cap. 1, p. 3-29). Barueri: Manole.

Pinheiro, M. M., Ciconelli, R. M., Chaves, G. V., Aquino, L., Juzwiak, C. R., Genaro, O. S., \& Ferraz, M. B. (2011). Antioxidant intake among Brazilian adults - The Brazilian Osteoporosis Study (BRAZOS), a cross-sectional study. Nutrition Journal, 10(39), 1-8.

Podda, M., Weber, C., Traber, M. G., \& Packer, L. (1996). Simultaneous determination of tissue tocopherols, tocotrienols, ubiquinols, and ubiquinones. Journal of Lipid Research, 37(4), 893-901. PMid:8732789.

Ramadan, M. F., \& Wahdan, K. M. M. (2012). Blending of corn oil with black cumin (Nigella sativa) and coriander (Coriandrum sativum) seed oils: Impact on functionality, stability and radical scavenging activity. Food Chemistry, 132(2), 873-879. http://dx.doi. org/10.1016/j.foodchem.2011.11.054

Ramalho, V. C., Silva, M. G., \& Jorge, N. (2006). Influência do extrato de alecrim sobre a estabilidade do a-tocoferol em óleo de soja submetido à termoxidação. Alimentos e Nutrição, 17(2), 197-202.

Romero, N., Robert, P., Masson, L., Ortiz, J., González, K., Tapia, K., \& Dobaganes, C. (2007). Effect of $\alpha$-tocopherol, $\alpha$-tocotrienol and Rosa mosqueta shell extract on the performance of antioxidant-stripped canola oil (Brassica sp.) at high temperature. Food Chemistry, 104(1), 383-389. http://dx.doi.org/10.1016/j.foodchem.2006.11.052

Sánchez-Pérez, A., Delgado-Zamarreño, M. M., Bustamante-Rangel, M., \& Hernández-Méndez, J. (2000). Automated analysis of vitamin $\mathrm{E}$ isomers in vegetable oils by continuous membrane extraction and liquid chromatography-electrochemical detection. Journal of Chromatography A, 881(1-2), 229-241. http://dx.doi.org/10.1016/ S0021-9673(00)00314-9

Schwartz, H., Ollilainen, V., Piironen, V., \& Lampi, A. (2008). Tocopherol, tocotrienol and plant sterol contents of vegetable oils and industrial fats. Journal of Food Composition and Analysis, 21(2), 152-161. http://dx.doi.org/10.1016/j.jfca.2007.07.012

Smolarek, A. K., \& Suh, N. (2011). Chemopreventive Activity of Vitamin E in Breast Cancer: A Focus on $\gamma$ - and $\delta$-Tocopherol. Nutrients, 3(11), 962-986. PMid:22254089 PMCid:PMC3257724. http://dx.doi.org/10.3390/nu3110962

Traber, M. G. (2006). Vitamin E. In B. A. Bowman \& R. M. Russel (Eds.), Present Knowledge in Nutrition (cap. 15, pp. 211-219). Washington: International Life Sciences Institute.

Traber, M. G. (2012). Vitamin E. In J. W. Erdman, I. A. MacDonald \& S. H. Zeisel (Eds.), Present Knowledge in Nutrition (cap. 14, pp. 383397). Oxford: Wiley-Blackwell.

United States Department of Agriculture - USDA. (2008). Agricultural Research Service. USDA National Nutrient Database for Standard Reference, Release 21. Retrieved from http://www.ars.usda.gov/ba/ bhnrc/ndl.

Universidade Estadual de Campinas - UNICAMP. (2011). Tabela brasileira de composição de alimentos - TACO (4. ed.) Campinas: NEPA/ UNICAMP.

Velasco, L., Del Moral, L., Pérez-Vich, B., \& Fernández-Martínez, J. M. (2010). Selection for contrasting seed tocopherol content in sunflower seeds. Journal of Agricultural Science, 148(4), 393-400. http://dx.doi.org/10.1017/S0021859609990608

Wallert, M., Schmölz, L., Galli, F., Birringer, M., \& Lorkowski, S. (2014). Regulatory metabolites of vitamin E and their putative relevance for atherogenesis. Redox Biology, 2, 495-503. PMid:24624339 PMCid:PMC3949092. http://dx.doi.org/10.1016/j. redox.2014.02.002

Zingg, J. M., \& Azzi, A. (2004). Non-antioxidant activities of vitamin E. Current Medicinal Chemistry, 11(9), 1113-1133. PMid:15134510. http://dx.doi.org/10.2174/0929867043365332 